\title{
Evidence for intensive walrus hunting by Thule Inuit, northwest Foxe Basin, Nunavut, Canada
}

\author{
Sean P. A. DESJARDINS \\ Department of Anthropology, McGill University, \\ 855 Sherbrooke Street West, Leacock Building, Room 718, \\ Montreal, Quebec H3A 2T7 (Canada) \\ sean.desjardins@mail.mcgill.ca
}

Desjardins S. P. A. 2013. - Evidence for intensive walrus hunting by Thule Inuit, northwest Foxe Basin, Nunavut, Canada. Anthropozoologica 48 (1): 37-51. http://dx.doi.org/10.5252/ az2013n1a2

\begin{abstract}
Although it is well known that modern Inuit in the resource-rich Foxe Basin region of Arctic Canada historically relied, and continue to rely, heavily on walrus, our knowledge of Thule Inuit walrus use in the area is limited. In this paper, new data is presented indicating walrus were being exploited intensively by Thule Inuit at NeHd-1 (Sanirajak), a winter site on the Foxe Basin coast of northeastern Melville Peninsula. Faunal remains from six large, discrete frontmiddens — each associated with a semisubterranean winter house - were examined. Of the specimens identified to species, walrus comprised nearly half of the aggregate sample; no archaeofaunal assemblage anywhere in the Canadian Arctic has produced so high a proportion. It is suggested that a pre-adaptation to organized, group hunting of both bowhead whales and walrus by Thule Inuit may have facilitated a year-round walrus-hunting industry centered on the acquisition and possible trade of reliably large amounts of meat, blubber, hides and ivory. An examination of walrus element frequencies at $\mathrm{NeHd}-1$ indicated the need for a meat utility index (MUI) specific to walrus, and a modified meat utility index (MMUI) that takes into account the desirability of ivory.

\section{RÉSUMÉ}

Témoignages de la chasse intensive au morse chez les Inuit thuléens du nord-ouest du bassin de Foxe, Nunavut, Canada.

KEY WORDS On sait que les Inuits modernes de la région du bassin de Foxe dépendaient, et continuent de dépendre, principalement des morses. Cependant, notre connaissance de l'utilisation du morse par les Inuits thuléens est limitée. Nous présentons dans cet article de nouvelles données indiquant que le morse était exploité de manière intensive chez les Inuits thuléens à NeHd-1 (Sanirajak), un site hivernal dans la région du bassin de Foxe. Les restes de faune de six
\end{abstract} Arctic, Nunavut,

Foxe Basin, Thule and modern Inuit, walrus, zooarchaeology. 


\author{
MOTS-CLÉS \\ Arctique, \\ Nunavut, \\ bassin de Foxe, \\ Inuits thuléens et \\ modernes, \\ chasseurs-cueilleurs, \\ morses, \\ archéozoologie.
}

grands dépotoirs distincts, chacun étant associé à une maison semi-souterraine d'hiver, ont été étudiés. Le morse représente près de la moitié de l'échantillon total des spécimens identifiés. Aucun autre assemblage faunique de l'Arctique canadien n'a produit une proportion de morse aussi élevée. Nous suggérons qu'une prédisposition à organiser une chasse de groupe à la baleine boréale et au morse aurait rendu possible la chasse au morse durant toute l'année, activité principalement centrée sur l'acquisition et le commerce éventuel de quantités importantes et fiables de viande, de graisse, de peaux et d'ivoire. Un examen des fréquences de représentation des restes de morse dans le site de $\mathrm{NeHd}-1$ indique le besoin d'un indice d'utilité de la viande (MUI) spécifique au morse, et un indice d'utilité de la viande modifiés (MMUI) qui prend en compte l'attrait de l'ivoire.

\section{INTRODUCTION}

The coastlines of northern Foxe Basin, Nunavut, are unique in the Eastern Arctic for their high densities of archaeological sites from every Canadian Arctic cultural tradition, from Pre-Dorset (ca 2500 to $500 \mathrm{BCE}$ ) to modern Inuit (Meldgaard 1960, 1962; Murray 1996). This continuity of settlement has been attributed to the region's relative ecological stability and abundance of animal resources - especially sea-mammals. Of particular interest are Atlantic walrus (Odobenus rosmarus rosmarus), found in high numbers year-round in Foxe Basin waters, and second only to bowhead whales in the amount of usable material provided per animal. Murray $(1996,1999)$ has established the importance of walrus to Early and Middle Dorset (ca. 500 $\mathrm{BCE}$ to AD 500) economies on Igloolik Island in northwest Foxe Basin. When Thule Inuit, ancestors of modern Inuit, entered the Eastern Arctic from western and northern Alaska around AD 1200 (Friesen \& Arnold 2008), they supplanted most Dorset groups in a poorly-understood fashion (see Friesen 2004 for an analysis of the transition), bringing with them a well-developed, open-water sea-mammal hunting tradition pre-adapted to walrus exploitation (Collins 1937; Arutiunov \& Sergeev 1968; Hill 2011).

Ethnographic evidence and explorers' accounts from the late nineteenth and early twentieth cen- turies indicate walrus were an important resource to Amitturmiut, the historic Inuit groups occupying the coasts of northern Foxe Basin (Parry 1824; Lyon 1825; Mathiassen 1928). As no detailed faunal analyses have been made available for any Thule Inuit site in the region, the nature of walrus use during these occupations is unclear, though the abundance of walrus in local waters, and the presence of sea-mammal cache features at area winter sites, suggests at the very least that walrus contributed significantly to the winter diets of Thule Inuit.

In this paper, I describe and interpret a faunal assemblage from NeHd-1 (Sanirajak), a Thule Inuit winter village of nine semisubterranean sodand-whale bone houses, characteristic of so-called "Classic" Thule Inuit winter occupations, located within the bounds of the modern Inuit community of Hall Beach (Fig. 1). Faunal material for this analysis was collected during the 2007 field season of the Sanirajak Project, led by Nunavut Territorial Archaeologist Julie M. Ross, and was initially examined as part of a Master of Science degree in Anthropology at the University of Toronto (Desjardins 2009). In my discussion of the data, I reference oral histories from area elders acquired from the Igloolik Research Center, as well as accounts of elders and hunters I collected in Igloolik during the summer of 2011. 


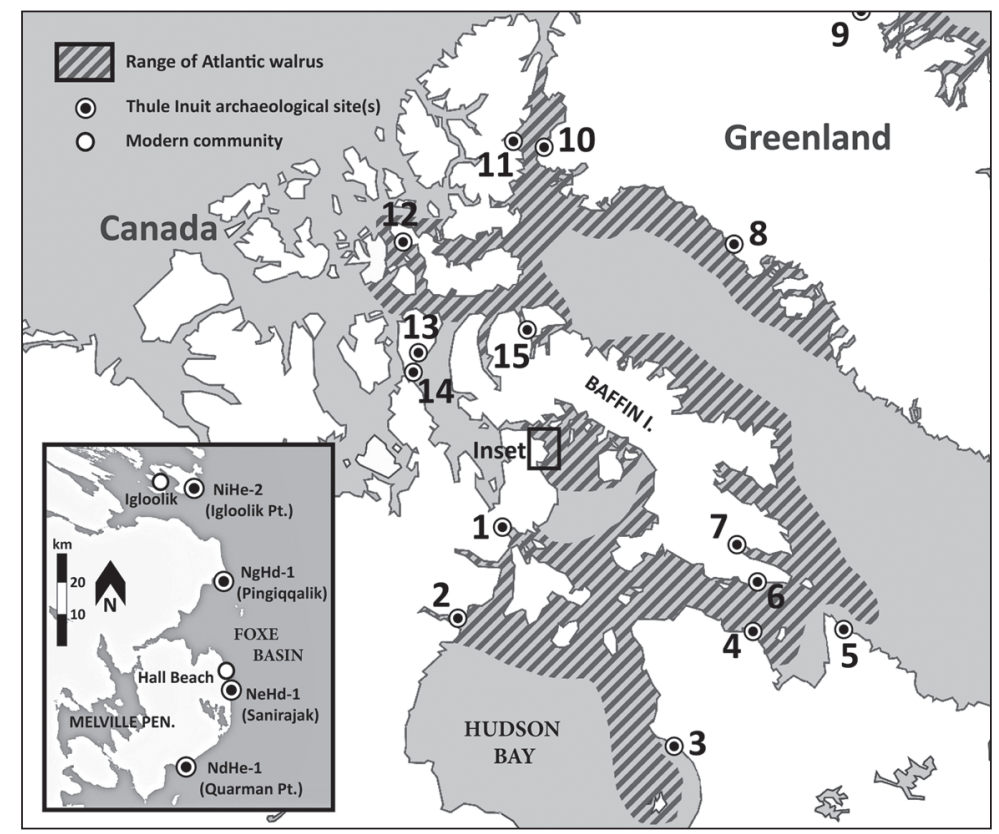

FIG. 1. - Map of the Eastern Arctic, showing the study area; the range of Atlantic walrus (data from Born et al. 1995); and Thule Inuit archaeological sites discussed in the text: 1) Naujan, 2) Silumiut, 3) Qijurittuq, 4) JfEl-10, 5) Nachvak Fiord, 6) Talaguak, 7) Peale Point, 8) Nugarasuk 9) Clavering Island, 10) Cape Grinnell, 11) Bache Peninsula Sites, 12) Porden Point, 13) Learmonth, 14) Cape Garry, and 15) Nunguvik.

\section{FIELD SETTING}

\section{RegionAl ECOLOGY}

Situated north of Hudson Bay, Foxe Basin is relatively shallow, averaging about 100 meters in depth, bounded to the west by the Melville Peninsula, and to the east by the rugged terrain of western Baffin Island. The areas traditionally occupied by Thule and modern Inuit are the marshy, coastal lowlands of the northeastern Melville Peninsula. Caribou (Rangifer tarandus) are the only large terrestrial mammals in the region regularly hunted by Inuit, primarily during late summer and early fall. Arctic foxes (Vulpes lagopus) are common in the area, as are Arctic hares (Lepus arcticus). Polar bears (Ursus maritimus) are present on both landfast and loose pack ice year round. The area features numerous shallow, freshwater bodies, many of which support large numbers of lake trout (Salvelinus namaycush) and Arctic char (Salvelinus alpinus).
During summer months, the coastlines as far north as Igloolik become largely ice-free, though loose pack ice, kept in constant motion by strong currents, is prevalent offshore. In the winter, firstyear landfast ice, reaching its maximum in May, can extend up to $15 \mathrm{~km}$ into the Basin. A series of small, recurring polynyas extending from Igloolik Island to Quarman Point serve as breeding sites for migratory birds (Stirling 1997). Importantly, these polynyas offer overwinter refuge for several varieties of sea-mammals. Gregarious ringed seals (Phoca hispida), found in high numbers, favour landfast ice, where they are hunted at their breathing holes; during the summer, they are acquired in the open water and on ice floes. Bearded seals (Erignathus barbatus), considerably larger in size, are hunted in the same manner, though their numbers are considerably lower (Beckett et al. 2008). Harp seals (Phoca groenlandicus) are occasionally present on ice floes far off the coast during summer months; due to their low numbers, and seasonal presence in Foxe Basin 


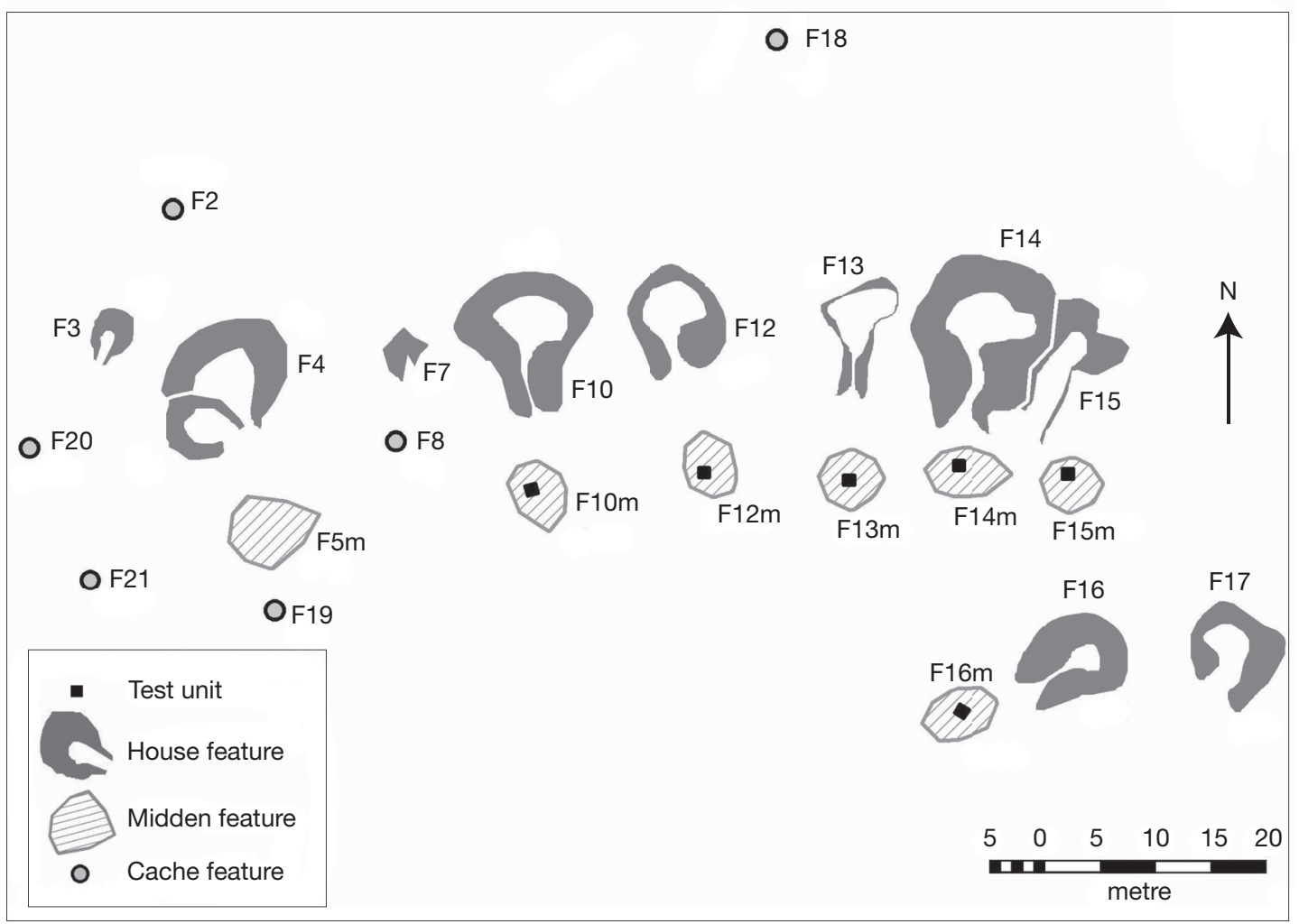

FIG. 2. - Site plan of NeHd-1 (map created by R. Hechler, S. P. A. Desjardins and S. Perry, Nunavut Department of Culture and Heritage).

waters, they have never contributed significantly to the Inuit diet in the area (Wenzel 1978). Bowhead whales (Balaena mysticetus) are frequently sighted by local Inuit hunters in northern Foxe Basin waters during summer months, though they are not regularly hunted today. Belugas (Delphinapterus leucas) and narwhals (Monodon monoceros), are present in variable numbers in the waters to the northwest of Igloolik Island; only narwhals are hunted by Inuit today, primarily for their skin and attached fat - a delicacy known as maktaaq.

While the occurrence of Atlantic walrus is relatively patchy across most of its extensive range in the Eastern Arctic, the exception is Foxe Basin, which boasts the largest herds in Eastern Arctic waters; walrus in the region are not known to venture beyond a 50,000 $\mathrm{km}^{2}$-area (Born et al. 1995; Outridge \& Stewart 1999), making them available in consistently high numbers, year-round. Conse- quently, Inuit of northern Foxe Basin hunt walrus during both summer and winter months, though open-water summer hunting is today far more common than winter hunting, which traditionally took place on moving pack ice (Ivalu 1996).

\section{NeHD-1 IN CONTEXT}

Approximately 325 kilometers northeast of Naujan, Mathiassen's (1927) type-site for Classic Thule Inuit culture, NeHd-1 is situated one-half kilometer north of the Foxe Basin shore on a broad, marshy plain. Prior to excavations by the Sanirajak Project field crews in 2006, 2007 and 2008, two cursory surveys were conducted by Van Norman (1955) and Thomson (1991), both of whom provided useful interpretations of site use. Long known to Hall Beach locals, NeHd-1 consists of nine semisubterranean winter houses dug deeply into a natural rise above the marsh, and two qarmat (shallow semisubterra- 


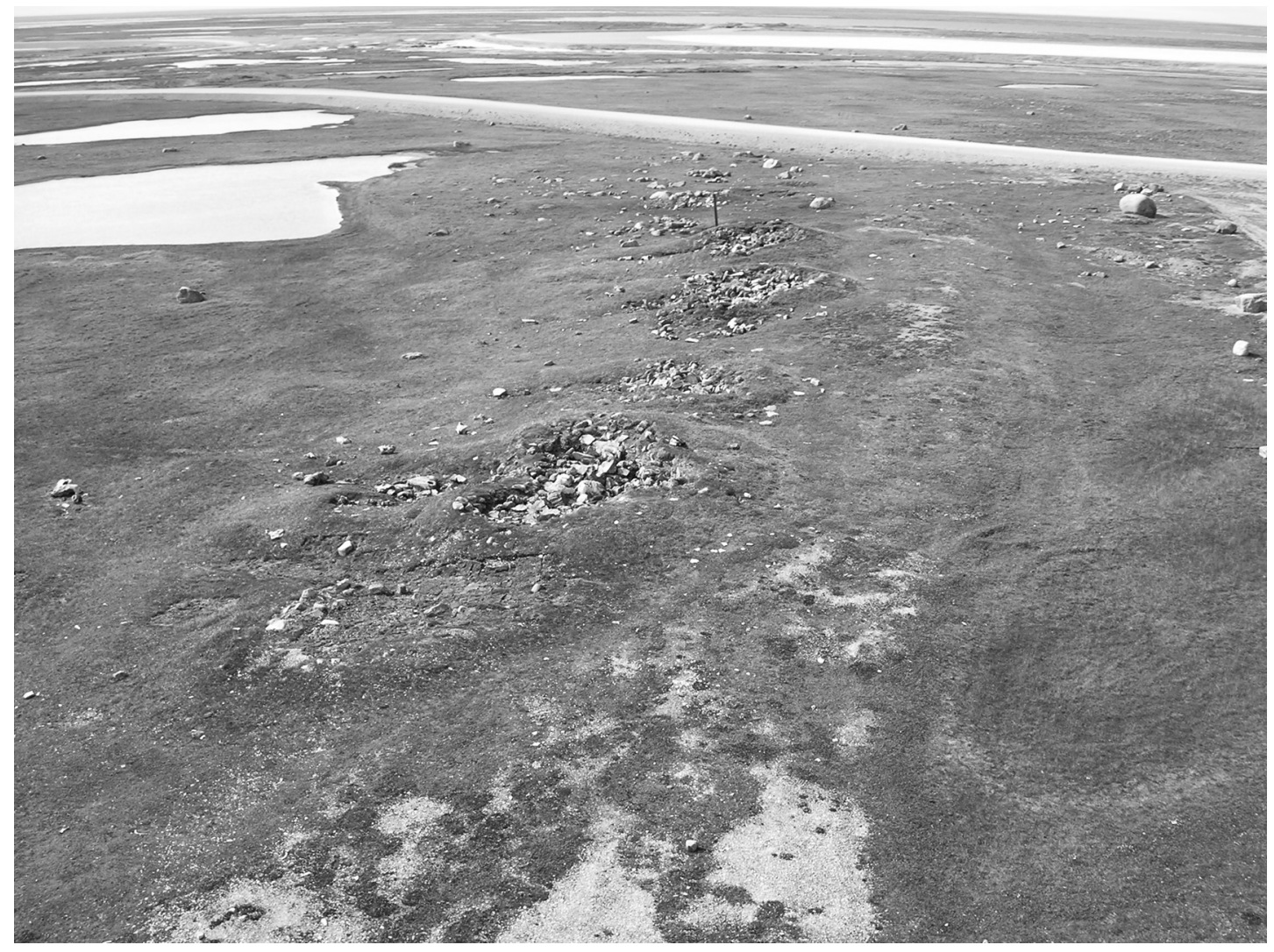

FIG. 3. - NeHd-1 (Sanirajak), main house row, facing east. (Photograph by J. M. Ross).

nean features occupied during fall months) at the southeast corner of the site (Figs 2; 3). The sloped ridge of the main house row provided elevation and natural drainage, as well as a break from northerly winds. Most of the house entrance passages are at least partly visible, and face the open water to the south; the only exceptions are F16 and F17, which have passages facing the southwest and southeast, respectively. F3, F4 and F5 are single-lobe structures; much of F5 truncates the western wall of the larger $\mathrm{F} 4$, and both features share a front-midden (F5M). F7 is most likely a single-lobe house, though it has been heavily disturbed, and little of the stone substructure remains.

The largest house, Feature 14, is a deeply-dug, trilobate structure, measuring approximately 11 x $8 \mathrm{~m}$; like F10, F14 has been heavily disturbed by natural slumping, and is largely devoid of sod cover, allowing an unobstructed view of internal structural elements, such as sleeping platforms. Seven houses (F5, F10, F12, F13, F14, F15 and F16) have prominent front middens rising from four to ten centimeters above the surface, oriented just southeast of the visible terminus of each entrance passage. In addition to house and midden features, five gravel sea-mammal caches (F2, F18, F19, F20 and F21) are scattered around the west end of the site. Though the Sanirajak Project field crews did not conduct a thorough count of large surface faunal elements, Thomson (1991:2) noted the presence of "at least 31 bowhead and 29 walrus crania," most of which were scattered across the eastern half of the site.

In addition to the midden features addressed in this paper, three house features have been fully excavated 
at $\mathrm{NeHd}-1$. F15 was excavated during the summers of 2006 and 2007, and produced an abundance of artifacts and faunal material. Objects of note include numerous ivory and antler harpoon heads, a whaling harpoon head with a radial incision pattern, and an ivory bow drill with an incised whaling scene. As in the midden samples, F15 also produced a large amount of ivory flakes, likely the result of reduction for tool manufacture. The smaller house features F3 and F5, both excavated in 2008, also yielded significant amounts of bone, ivory debitage and characteristic classic Thule Inuit artifacts.

No radiocarbon dates have yet been processed for the excavated features at NeHd-1. Sod- and whalebone architecture, the abundance of slate-blade technology and the corresponding absence of any metal artifacts indicate the features thus far excavated (F3, F5 and F15), as well as the midden features analyzed in this analysis, most likely date to Classic Thule Inuit times (ca. AD 1200 to 1500). In some ways, the difficulty in situating the $\mathrm{NeHd}-1$ samples chronologically reflects the broader problem of interpreting the poorly-defined cultural transition from Thule to modern Inuit. The traditional subsistence economy of northern Foxe Basin lasted longer than that of almost any other region in the Eastern Arctic, nearly 150 years after W. E. Parry's initial contact with Amitturmiut in 1822. The seasonally-mobile hunting lifestyle, dominated by strict resource scheduling, continued unabated for many in the region until the Canadian government provided subsidized housing in the planned nodal communities of Hall Beach and Igloolik in 1966 (Crowe 1970). On Kapuivik (Jens Munk Island), the region's last permanent, single-family outpost camp was abandoned in 2010 (Allurut 2011, pers. comm.).

Damas (1963: 32) suggests the leadership structure, subsistence focus and large populations of the seasonal camps operating in the area until the early 1960s were most likely similar to those of Thule Inuit utilizing the same sites centuries earlier. The likely continuity not only of subsistence practices and social organization, but also of settlement, is important; northern Foxe Basin was never abandoned by Thule Inuit, and the transition to "modern Inuit" occurring from around AD 1400 to the twentieth century is difficult to define, partly due to the lack of archaeological interest in these transitional Inuit lifeways.

Geographically, NeHd-1 is surrounded by prominent hunting camps with long histories of steady, seasonal re-occupation from Thule Inuit times to the early twentieth century. The large village sites at Quarman Point (NdHe-1), $30 \mathrm{~km}$ southwest of $\mathrm{NeHd}-1$, and Igloolik Point (NiHe-2), on the southeast coast of Igloolik Island, are each dominated by at least a dozen robust Thule Inuit winter houses and numerous gravel sea-mammal caches. Both sites were occupied during winter months well into the 1950s (Crowe 1970: 39-42).

The most prominent early Inuit site in the region is arguably Pingiqqalik ( $\mathrm{NgHd}-1$ ), an unusually large winter village $37 \mathrm{~km}$. north of $\mathrm{NeHd}-1$, consisting of at least 60 semisubterranean sod houses (many with architectural whale bone) and dozens of qarmat and sea-mammal cache features scattered along a series of raised beach ridges. Mary-Rousselière (1954) recounts an Igloolik elder's statement that some sod house features were occupied during winter months in the mid nineteenth century. Mathiassen (1928) notes that by 1924 , the site area was occupied by only a small number of people. During a visit to Pingiqqalik with the author in 2011, Igloolik elder Herve Paniaq remarked that the area was ideal for walrus hunting, as favorable northeasterly winds brought pack ice to the floe edge in largely predictable ways. This would have allowed Thule and historic Inuit hunters access to walrus haul-out sites on the moving ice. Like Pingiqqalik, NeHd-1 sits adjacent to the open coast of Foxe Basin; site residents likely benefited from similar environmental conditions favoring winter walrus hunts.

\section{METHODS}

During the 2007 Sanirajak Project field season, a $1 \mathrm{x}$ 1-metre test unit was placed in each of six of the seven prominent front middens at NeHd-1 (F10-F16). Each unit was excavated by trowel in arbitrary $10-\mathrm{cm}$ levels to culturally-sterile beach sand. The top layer of each unit, consisting of sod with surface gravel and bone, was not included in this analysis. (These units will hereafter be referred to as " $\mathrm{M}$ " midden 
tests, associated with their corresponding site features (e.g., F13M)). Dark organic soils dominated all levels. Sterile soils were encountered at $60 \mathrm{~cm}$ in F10M, F12M and F13M; $50 \mathrm{~cm}$ in F15M; $30 \mathrm{~cm}$ in F13M; and $80 \mathrm{~cm}$ in F14M, which produced the most faunal material of all the midden sample test units. All excavated material was either bagged on site (in the case of larger fragments and elements), or screened through $1.9-\mathrm{cm}(3 / 4-i n)$ mesh. All faunal remains were cleaned and identified at the zooarchaeology laboratory at the University of Toronto.

Each of the midden sample test units contained a large number of small, dense, cleanly-broken fragments-likely portions of walrus crania, though some were possibly post-cranial bearded seal fragments. Remains of large pinnipeds, especially robust walrus fragments and complete elements, dominated most levels of each test unit. This may explain why the overall NISP was not higher, as well as why the front midden features themselves were so sizable; large numbers of complete or nearly-complete walrus elements occupy much space.

There are a number of potential problems raised by drawing conclusions on subsistence activities from analyses of bones from midden features alone. Differential taxonomic representation between houses and middens resulting from periodic removal of robust bones from houses, and subaerial bone weathering and carnivore gnawing of less robust fragments in middens, has been documented in an Arctic context by Friesen $\&$ Betts (2004). They argue convincingly that both house and midden contexts should be sampled in order to gain a complete picture of specialized and generalized subsistence activities at a site. Below, I note instances when questions arising from $\mathrm{NeHd}-1$ midden fauna could be addressed through an analysis of corresponding house fauna. Among fauna in the midden samples, the presence of soft tissue on some larger sea-mammal elements, and a minimal amount of carnivore gnawing on all identified mammal remains ( $\mathrm{N}=147$ / 2794, 5.2\%), suggests preservation was excellent, and the effects of taphonomic processes that may have affected smaller specimens in the sample were minimal. I believe in the case of $\mathrm{NeHd}-1$, data from the midden samples provide a strong indication of generalized subsistence trends across occupations at the site. However, it is hoped the faunal samples of the fully excavated house features at NeHd-1 will eventually be evaluated against the midden data presented here.

\section{RESULTS}

\section{TAXONOMIC FREQUenCIES}

Taxonomic frequencies from all midden features are presented in Table 1. As species representation is relatively consistent across the samples, they were aggregated to provide a single data set with which to derive information on element frequency for walrus, which dominated the NISP and MNI in every midden sampled, as well as to make comparisons with Thule Inuit faunal datasets from across the Eastern Arctic. The relative dearth of ringed seal in all midden contexts at NeHd-1 was surprising; ringed seals are available in high numbers year-round throughout the Canadian Arctic, and are considered a key staple in all coastal North American Arctic contexts (Damas 1969; McGhee 1984). This low frequency may be related to the high frequency of walrus in the sample; in large numbers, walrus are known to frighten and drive away ringed seal populations (Freeman 1984: 42). Also interesting is the relative abundance of bearded seals in the samples - only slightly more frequent than ringed seals across midden contexts. Bearded seals are benthic feeders, requiring shallow waters; though non-migratory, their occurrence in northwest Foxe Basin is usually difficult to predict. Caribou distribution across midden samples is relatively consistent, though overall numbers are low. It is possible more caribou bones are to be found in the house contexts, as high utility elements transported back to the site from the place of butchery may have undergone further processing for marrow inside the houses (Howse 2008: 30).

The complete absence of fish in the sample is typical of many Thule Inuit contexts (see Whitridge 2001 for a discussion of the problems associated with indentifying evidence of Thule Inuit fish exploitation); Migratory waterfowl did not contribute significantly to the assemblage of any midden sample, indicating they may not have been regularly hunted, and were taken infrequently as opportunity arose. It is possible bird elements - often small, and 
TABLE 1. - Taxonomic frequencies for all NeHd-1 midden samples. 1 Bird specimens were infrequent and largely fragmented; most specimens could not be identified to species. 2 "Large pinniped" comprised very small, dense fragments, likely parts of walrus crania or bearded seal post-cranial elements. These fragments are not included in the mammalian NISP tally. 3 Bivalves (mostly clam) are intrusive, and are not included in the total specimen count.

\begin{tabular}{|c|c|c|c|c|c|c|c|c|c|c|c|c|c|c|c|c|c|c|c|c|c|}
\hline \multirow[t]{2}{*}{ Taxon } & \multicolumn{3}{|c|}{ F10M } & \multicolumn{3}{|c|}{ F12M } & \multicolumn{3}{|c|}{ F13M } & \multicolumn{3}{|c|}{ F14M } & \multicolumn{3}{|c|}{ F15M } & \multicolumn{3}{|c|}{ F16M } & \multicolumn{3}{|c|}{ Aggregate } \\
\hline & $\mathbf{z}$ & $\frac{0}{\frac{0}{2}}$ & $\bar{\Sigma}$ & $\mathbf{z}$ & 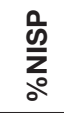 & $\overline{\mathbf{z}}$ & $\mathbf{z}$ & 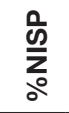 & $\overline{\mathbf{\Sigma}}$ & $\mathbf{z}$ & 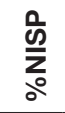 & $\bar{\Sigma}$ & $\mathbf{z}$ & 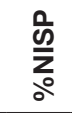 & $\bar{\Sigma}$ & $\mathbf{z}$ & $\frac{0}{\frac{0}{2}}$ & $\bar{\Sigma}$ & $\mathbf{z}$ & 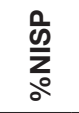 & $\bar{\Sigma}$ \\
\hline ptarmigan & 1 & 17 & 1 & 0 & 0 & 0 & 0 & 0 & 0 & 1 & 4.8 & 1 & 0 & 0 & 0 & 0 & 0 & 0 & 2 & 5.5 & 2 \\
\hline eider & 5 & 83 & 1 & 2 & 25 & 1 & 0 & 0 & 0 & 18 & & 3 & 1 & 100 & 1 & 0 & 0 & 0 & 26 & 72.2 & 6 \\
\hline goose & 0 & 0 & 0 & 6 & 75 & 2 & 0 & 0 & 0 & 1 & 4.8 & 1 & 0 & 0 & 0 & 0 & 0 & 0 & 7 & 19.4 & 3 \\
\hline gull & 0 & 0 & 0 & 0 & 0 & 0 & 0 & 0 & 0 & 1 & 4.8 & 1 & 0 & 0 & 0 & 0 & 0 & 0 & 1 & 2.8 & 1 \\
\hline bird NISP1 & 6 & - & - & 8 & - & - & 0 & - & - & 21 & - & - & 1 & - & - & 0 & - & - & 36 & - & - \\
\hline indet. bird & 8 & - & - & 12 & - & - & 6 & - & - & 34 & - & - & 19 & - & - & 8 & - & - & 87 & - & - \\
\hline Total bird & 14 & 100 & 2 & 20 & 100 & 3 & 6 & 0 & 0 & 55 & 100 & 6 & 20 & 100 & 1 & 8 & 0 & 0 & 159 & 100 & 12 \\
\hline Arctic fox & 14 & 7.4 & 1 & 6 & 2.4 & 2 & 5 & 4 & 1 & 21 & 5.4 & 1 & 4 & 4.9 & 1 & 5 & 8.9 & 1 & 55 & 5 & 7 \\
\hline Canis sp. & 10 & 5.3 & 1 & 13 & 5.2 & 1 & 8 & 6.5 & 1 & 11 & 2.8 & 1 & 8 & 9.9 & 1 & 1 & 1.8 & 1 & 51 & 4.7 & 6 \\
\hline caribou & 10 & 5.3 & 1 & 29 & 12 & 2 & 18 & 15 & 1 & 29 & 7.5 & 1 & 9 & 11 & 2 & 4 & 7.1 & 1 & 99 & 9.1 & 8 \\
\hline polar bear & 0 & 0 & 0 & 1 & 0.4 & 1 & 1 & 0.8 & 1 & 0 & 0 & 0 & 0 & 0 & 0 & 0 & 0 & 0 & 2 & 0.2 & 2 \\
\hline ringed seal & 13 & 6.8 & 1 & 10 & 4 & 2 & 7 & 5.7 & 1 & 79 & 20 & 3 & 21 & 26 & 1 & 11 & 20 & 1 & 141 & 13 & 9 \\
\hline bearded seal & 47 & 25 & 2 & 42 & 17 & 2 & 14 & 11 & 1 & 75 & 19 & 2 & 10 & 12 & 1 & 11 & 20 & 1 & 199 & 18.3 & 9 \\
\hline walrus & 96 & 51 & 3 & 148 & 59 & 8 & 70 & 57 & 3 & 173 & 45 & 6 & 29 & 36 & 2 & 24 & 43 & 2 & 540 & 49.7 & 24 \\
\hline mammal NISP & 190 & - & - & 249 & - & - & 123 & - & - & 388 & - & - & 81 & - & - & 56 & - & - & 1087 & - & - \\
\hline cetac & 8 & - & - & 1 & - & - & 1 & - & - & 11 & - & - & 1 & - & - & 0 & - & - & 22 & - & - \\
\hline large pinniped2 & 57 & - & - & 224 & - & - & 102 & - & - & 340 & - & - & 37 & - & - & 33 & - & - & 793 & - & - \\
\hline indet. mammal & 122 & - & - & 214 & - & - & 92 & - & - & 297 & - & - & 112 & - & - & 55 & - & - & 892 & - & - \\
\hline Total mammal & 377 & 100 & 9 & 688 & 100 & 19 & 318 & 100 & 9 & 1036 & 100 & 14 & 231 & 100 & 8 & 144 & 100 & 7 & 2794 & 100 & 65 \\
\hline bivalve 3 & 1 & - & 1 & 1 & - & 1 & 2 & - & 2 & 1 & - & 1 & 0 & - & 0 & 1 & - & 1 & 6 & - & 6 \\
\hline indet. & 25 & - & - & 181 & - & - & 63 & - & - & 349 & - & - & 14 & - & - & 10 & - & - & 642 & - & - \\
\hline Total & 416 & - & - & 889 & - & - & 387 & - & - & 1440 & - & - & 265 & - & - & 162 & - & - & 3595 & - & 77 \\
\hline
\end{tabular}

relatively unobtrusive - were disposed of within the houses after processing and consumption; the 2007 field crew noted long bones of waterfowl within cultural layers of F15, along with several complete raven wings, which were apparently used to pad the structure's two sleeping platforms.

Of all specimens identified to species, walrus comprise $48 \%$ of the total sample as a proportion of the NISP (540/1123), and 36.9\% of the total MNI for mammals (24/65). As a percentage of the NISP (excluding unidentified specimens), no previouslyrecorded Thule Inuit faunal assemblage has produced a proportion of walrus remains so high. Previouslyrecorded faunal data on walrus abundance as a proportion of the NISP at 15 Thule Inuit sites (or site groups) in the Eastern Arctic are presented in Table 2. With the exception of the Learmonth and Cape Garry sites, all of these sites are within the range of walrus, though all are within regions where access to the animal is at least partly restricted seasonally (Born et al. 1995). Additionally, the percentage of walrus at NeHd-1 exceeds that at any Pre-Dorset or Dorset site for which detailed faunal data are available (see Murray 1999; Dyke et al. 1999).

Modifications to examined mammal bones at NeHd-1 were infrequent, but fairly uniform across midden contexts. Out of a total of 2,794 mammal specimens, $5.4 \%(\mathrm{n}=151)$ had cut marks; the majority of these $(n=60)$ were walrus rib fragments, with cut marks being largely consistent with disarticulation and meat removal. Burned fragments constituted only $5 \%$ of specimens $(n=140)$. All observed caribou long bone elements had spiral fractures, consistent with marrow extraction.

\section{WALRUS ELEMENT FREQUENCIES AND IVORY}

Walrus element frequencies for all midden samples are presented in Table 3. Given the large size of 
TABLE 2. - Occurrence of walrus remains as a proportion of the NISP (including fish and birds, but excluding cetacean remains) at Thule Inuit archaeological sites across the Eastern Arctic. 1 Mammal remains only. 2 Walrus count includes "large seals". 3 Comprises 'late' Thule and historic Inuit components. 4 NISP extrapolated from percentages; sample comprises both 'late' and 'early' Thule Inuit components.

\begin{tabular}{lccc}
\hline Site(s) & NISP Walrus / Total & \%Walrus & Source \\
\hline Cape Garry & $1 / 2819$ & 0.03 & Rick 1980 \\
Nugarasuk & $24 / 26735$ & 0.08 & Møhl 1979 \\
Nachvak Fd. & $11 / 5695$ & 0.2 & Swinarton 2008 \\
Learmonth & $4 / 1458$ & Rick 1980 \\
Porden Pt. & $45 / 10782$ & 0.3 & Park 1989 \\
Peale Pt. & $104 / 178301$ & 0.4 & Stenton 1987 \\
Talaguak & $138 / 96862$ & 0.6 & Sabo 1981 \\
Silumuit & $706 / 29848$ & 1.4 & Staab 1979 \\
Cape Grinnell & $143 / 3387$ & 2.4 & Darwent \& Foin 2010 \\
Qijurittuq & $55 / 13103$ & 4.2 & Desrosiers et al. 2010 \\
Learmonth & $102 / 2320$ & 4.2 & Taylor and McGhee 1979 \\
JfEl-10 & $76 / 1128$ & 4.4 & Lofthouse 2003 \\
Nunguvik & $278 / 41004$ & 6.7 & Mary-Rousselière 1976 \\
Bache Pen. & $1097 / 15739$ & 6.8 & McCullough 1989 \\
Clavering Island & $699 / 9498$ & 7 & Gotfredsen 2010 \\
NeHd-1 (Sanirajak) & $540 / 1123$ & 7.4 & - \\
\hline
\end{tabular}

walrus, transporting even the elements of highest utility from the place of capture and butchery to a village site is no small task. In all samples but one - F16M - cranial elements predominated; the high value of mandibles in the very small F16M sample is attributable to the presence of two complete adult walrus mandibles. Post-cranial elements are less frequent across midden contexts. With the exception of ribs, axial elements are rare in the aggregate sample. While it is possible that these elements were transported into the houses for consumption and eventual deposition, their large size would have been obtrusive in even the most spacious multi-person dwelling. If these elements had been brought into the houses for food preparation, they would likely have been removed to the midden shortly after. Therefore, the low frequency of these elements strongly suggests meat was removed before transport to the village site. Scapulae are well represented; associated front limb elements forming the shoulder girdle are only slightly less frequent.

Given the abundance of cranial elements, frequencies were calculated with and without crania and elements expected to be found with whole crania (e.g., atlas vertebrae, cervical vertebrae, and mandibles) (Fig. 4). The results of this calculation show more clearly the economic importance of the shoulder and ribs. According to Igloolik elder George Kappianaq (1997), the most desired

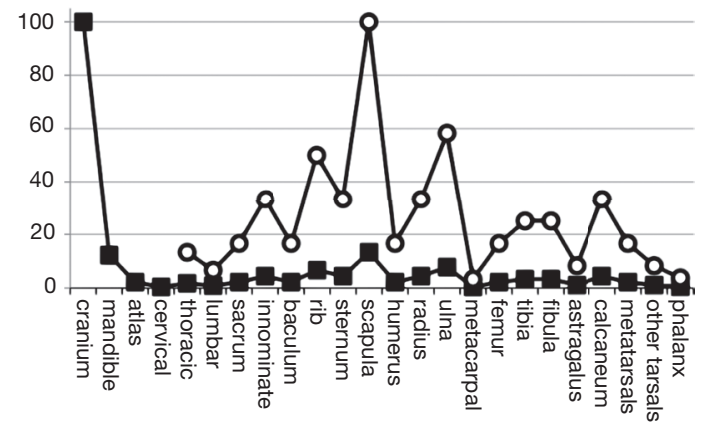

FIG. 4. - Walrus body part frequencies for midden samples at $\mathrm{NeHd}-1$, with (squares) and without (circles) crania and associated elements.

postcranial portions of a walrus were traditionally the "shanks" (large portions of meat surrounding the shoulder and upper front limbs). Hind flipper elements are relatively well-represented in the NeHd-1 sample; both front and hind flippers are considered delicacies by local Inuit, and are often returned whole (Allurut 2011; Kunuk 1998). The high frequency of innominate bones, scapulae and flipper elements is interesting, considering the relative infrequency of mid-limb elements. Humeri and femora are large bones from which meat can be removed easily. It is likely differential selection for "shanks" and flippers was occurring at NeHd-1. 
TABLE 3. - Walrus element frequencies for all NeHd-1 midden samples. The maxilla was the most frequently encountered cranial element, and was used to calculate the MNE for crania.

\begin{tabular}{|c|c|c|c|c|c|c|c|c|c|c|c|c|c|c|c|c|c|c|c|c|c|}
\hline \multirow[t]{2}{*}{ Element } & \multicolumn{3}{|c|}{ F10M } & \multicolumn{3}{|c|}{ F12M } & \multicolumn{2}{|c|}{ F13M } & \multicolumn{3}{|c|}{ F14M } & \multicolumn{3}{|c|}{ F15M } & \multicolumn{3}{|c|}{ F16M } & \multicolumn{4}{|c|}{ Aggregate } \\
\hline & 岂 & $\stackrel{2}{\Sigma}$ & 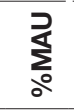 & 岂 & $\stackrel{?}{\Sigma}$ & $\sum_{0}^{2}$ & $\underset{\Sigma}{\mathbf{\Sigma}}$ & $\stackrel{2}{\overleftarrow{\Sigma}}$ & 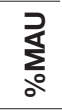 & $\underset{\mathbf{Z}}{\mathbf{Z}}$ & $\stackrel{2}{\Sigma}$ & $\sum_{0}^{2}$ & $\underset{\Sigma}{\mathbf{Z}}$ & $\stackrel{2}{\Sigma}$ & $\sum_{0}^{2}$ & $\frac{\mathrm{W}}{\mathbf{\Sigma}}$ & $\stackrel{2}{\Sigma}$ & 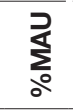 & 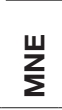 & $\underset{\Sigma}{\stackrel{2}{\Sigma}}$ & 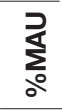 \\
\hline anium & 3 & 3 & 100 & 19 & 19 & 100 & 6 & 6 & 100 & 14 & 14 & 100 & 2 & 2 & 100 & 1 & 1 & 50 & 45 & 45 & 100 \\
\hline & 2 & 1 & 33.3 & 1 & 0.5 & 2.6 & 1 & 0.5 & 8.3 & 2 & & & 1 & 0.5 & 25 & 4 & 2 & 100 & 11 & 5.5 & 12.2 \\
\hline & 0 & 0 & 0 & 0 & 0 & 0 & 0 & 0 & 0 & 1 & 1 & 7 & 0 & 0 & 0 & 0 & 0 & 0 & 1 & 1 & 2.2 \\
\hline & 0 & 0 & 0 & 0 & 0 & 0 & 0 & 0 & 0 & & 0.2 & 1.4 & 0 & & & 0 & & & 1 & 0.2 & 0.4 \\
\hline & 1 & 0.06 & 2 & 2 & 0.1 & 0.7 & 1 & 0.06 & 1 & 7 & & 3.3 & 1 & 0.06 & 3 & 0 & c & 0 & 12 & 0.8 & 1.8 \\
\hline & 0 & 0 & 0 & 0 & 0 & 0 & 0 & 0 & 0 & 2 & 0.4 & 2.9 & 0 & 0 & 0 & 0 & 0 & 0 & 2 & 0.4 & 0.9 \\
\hline & 0 & 0 & 0 & 0 & 0 & 0 & 0 & 0 & 0 & & & 7 & & & & & & & 1 & & 2.2 \\
\hline nate & 0 & 0 & 0 & 1 & 0.5 & 2.6 & 1 & 0.5 & 8.3 & 2 & & 7 & 0 & c & 0 & 0 & 0 & 0 & $t$ & 2 & 4.4 \\
\hline & 0 & 0 & 0 & 0 & 0 & 0 & 0 & 0 & 0 & 1 & 1 & 7 & & & 0 & & 0 & 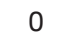 & & 4 & 2.2 \\
\hline & 11 & 0.4 & 12 & 13 & 0.4 & 2.3 & 15 & 0.5 & 8.3 & 32 & 1.1 & 7.6 & 9 & 0.3 & 15 & 10 & 0.3 & 16.5 & 90 & 3 & 6.7 \\
\hline & 0 & 0 & 0 & 0 & 0 & 0 & 0 & 0 & 0 & 2 & 2 & 14.3 & 0 & 0 & 0 & 0 & 0 & 0 & 2 & 2 & 4.4 \\
\hline & 2 & 1 & 33.3 & 5 & 2.5 & 13.1 & 1 & 0.5 & 8.3 & 3 & 1.5 & 10.7 & 0 & & & 1 & 0.5 & 25 & 12 & 6 & 13.3 \\
\hline & 0 & 0 & 0 & 0 & 0 & 0 & 0 & 0 & 0 & 1 & 0.5 & 3.6 & 1 & 0.5 & 25 & 0 & 0 & 0 & 2 & 1 & 2.2 \\
\hline & 0 & 0 & 0 & 2 & 1 & 5.2 & 0 & 0 & & & & 7 & 0 & 0 & 0 & 0 & & & 4 & 2 & 4.4 \\
\hline & 0 & 0 & 0 & 2 & 1 & 5.2 & 0 & 0 & 0 & 4 & 2 & 14.3 & 1 & 0.5 & 25 & 0 & 0 & 0 & 7 & 3.5 & 7.8 \\
\hline & 0 & 0 & 0 & 0 & 0 & 0 & & 0 & 0 & & 0.2 & 1.4 & 0 & & 0 & & & & 2 & 0.2 & 0.4 \\
\hline & 0 & 0 & 0 & 0 & 0 & 0 & 0 & 0 & 0 & & 1 & 7 & & & & 0 & & & 2 & 1 & 2.2 \\
\hline & 1 & 0.5 & 16.6 & 1 & 0.5 & 2.6 & 0 & 0 & 0 & 1 & 0.5 & 3.6 & 0 & 0 & 0 & 0 & 0 & 0 & 3 & 1.5 & 3.3 \\
\hline & 0 & 0 & 0 & 1 & 0.5 & 2.6 & & 0.5 & 8.3 & & & & & & & & & & & & 3.3 \\
\hline & 0 & 0 & 0 & 0 & 0 & 0 & 0 & 0 & 0 & 1 & & 3.6 & 0 & 0 & 0 & 0 & 0 & 0 & 1 & 0.5 & 1.1 \\
\hline & 0 & 0 & 0 & 2 & 1 & 5.2 & 0 & 0 & 0 & 2 & & 3.6 & 0 & 0 & 0 & 0 & & & 4 & 2 & 4.4 \\
\hline & 1 & 0.1 & 3.3 & 1 & 0.1 & 0.5 & 1 & 0.1 & 1.6 & 3 & 0.3 & 2.1 & 2 & 0.2 & 10 & 2 & 0.2 & 10 & 10 & 1 & 2.2 \\
\hline & 0 & 0 & 0 & 0 & 0 & 0 & 1 & 0. & 1. & 0 & 0 & 0 & 0 & 0 & 0 & 0 & 0 & 0 & 1 & 0.1 & 0.2 \\
\hline phalanx & 2 & 0.03 & 1 & 2 & 0.03 & 0.2 & 2 & 0.03 & 0.5 & 6 & 0.1 & 0.7 & 1 & 0.01 & 0.5 & 0 & 0 & 0 & 13 & 0.2 & 0.5 \\
\hline
\end{tabular}

Most significant, perhaps, is the head and its ivory. Both male and female walrus have large, dense tusks; the 24 individual walrus in the aggregate sample represent 48 tusks. Unfortunately, detailed data for ivory in the midden samples is not available, though ivory debitage was abundant in all levels of all midden samples, and a large number of the artifacts recovered from $\mathrm{F} 15$ were composed of ivory. The head of a walrus is heavy and fleshy; its bone is robust and dense. Igloolik elder Enuki Kunuk (1998) recounts that when hunting walrus in days past, the whole head was returned to the village site only when tools were not available to remove the posterior portion of the skull; more often, a cleaver or axe would be used to split the cranium laterally-across the coronal suture-to separate the anterior portion from the rest of the skull. Only this tusk-bearing portion would be returned to the village site. In describing walrus cranial processing and ivory reduction among Late Dorset groups in the High Arctic, LeMoine \& Darwent (1998) note the same technique as a possible first step in processing a walrus skull for tusk extraction.

If this activity was occurring at $\mathrm{NeHd}-1$, an abundance of anterior cranial elements should be expected at the village site. Of the aggregate walrus cranial NISP, maxilla fragments comprised $43 \%$ of the total; frontal bones, $7.8 \%$; temporal bones, $15.6 \%$; parietal bones, $16.6 \%$; occipital bones, $5 \%$; and mandibles, $7.8 \%$. The high number of maxilla fragments in the NeHd-1 sample is likely evidence of cranial processing for tusks. The next step would have been to remove the tusks from the maxillary sockets either by chopping directly at the upper portion of the socket to loosen the tusks, or by splitting the socket longitudinally. Either method would have resulted in high fragmentation of the maxillae and any other attached cranial elements. 
As cut marks on cranial elements were infrequent $(\mathrm{n}=19 / 217,8.7 \%)$, and most maxilla fragments had fairly clean longitudinal breaks, tusk extraction at $\mathrm{NeHd}-1$ would likely have involved breaking apart the anterior portion of the maxillae.

How the desire for ivory may have influenced walrus transport strategies is of particular interest. Meat, or food, utility indices are species-specific measures of usable soft tissue (meat, sculp and viscera) associated with individual elements or body parts of an animal. Modified utility indices combine body parts likely to be transported together, based on ethnographically-observed butchery practices (Binford 1978). Unfortunately, no meat utility index is available for walrus; the closest analog is an MUI (and MMUI) for California sea lions (Zalophus californianus), derived by Savelle et al. (1996). These two indices were plotted against the MAU for walrus in the $\mathrm{NeHd}-1$ aggregate sample, both with and without crania and associated elements. All four comparisons showed a weak positive, though statistically-insignificant correlation. The 'complete' and 'post-cranial' NeHd-1 subsets were more strongly (and significantly) correlated with the sea lion MUI, which is based solely on soft-tissue weights of individual body parts (total: rs $=0.3094, \mathrm{P}=0.28$; post-cranial: $\mathrm{rs}=0.3986$, $\mathrm{P}=0.19$ ) (Fig. 5), than with the derived MMUI (total: $r s=0.1635, \mathrm{P}=0.57$; post-cranial: $\mathrm{rs}=0.2363$, $\mathrm{P}=0.45)$. These comparisons reinforce the need for a new meat utility index accounting for the morphological uniqueness of walrus - the only surviving species of the Odobenidae family - as well as a modified index addressing the desirability of ivory, and the difficulties of hunting and butchering large animals on moving ice.

When walrus crania are excluded from the $\mathrm{NeHd}$ 1 sample, the mix of high-and low-utility elements indicates a transport strategy specific to the hunting of walrus fairly close to the village site during winter months. Among Amitturmiut, walrus acquired during summer months were traditionally fieldbutchered into easily-transportable skin pouches (known as ungirlaaq), largely free of bones, for later caching on the region's raised gravel beach ridges.

Today, butchery during winter months is carried out in similar ways, though this is a recent phenomenon. Igloolik elder Nathan Qamaniq (1999) notes

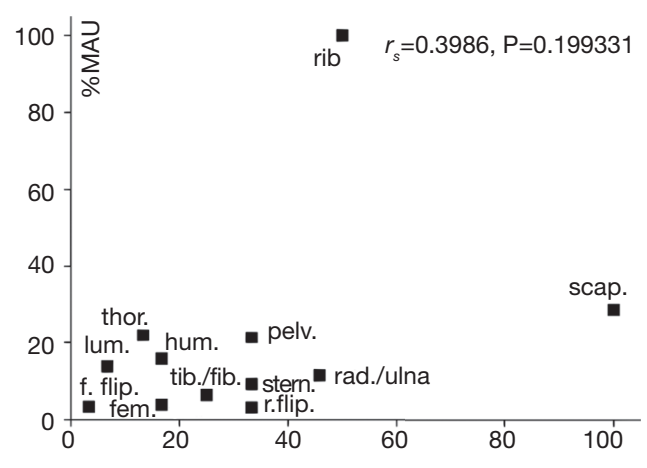

FIG. 5. - \%MUI values (for sea lions, after Savelle et al. 1996) and $\% \mathrm{MAU}$ values for walrus in the $\mathrm{NeHd}-1$ aggregate sample.

that traditionally, "[t]he sides and the belly section were removed in one whole pieces and load them [sic] on to the sled, but now we tend to cut them into smaller pieces. [...] Now we butcher them the way we would in the summer". Less meat was removed from bones, and more of the carcass was transported to village sites; large teams of dogs were brought on winter hunts to drag heavy catches from kill to village sites (Lyon 1825; Haulli \& Haulli 1987; Ijjangiaq \& Nutarakittuq 1987).

\section{DISCUSSION AND CONCLUSION}

A major difficulty in interpreting subsistence strategies among Thule Inuit is our inability to determine the degree to which bowhead whales contributed to the diets. Bowhead crania, scapulae, vertebrae and ribs - all elements favoured in semisubterranean winter house construction - have been found at Thule Inuit winter sites across the Eastern Arctic (Patton 1996; Savelle 1997; Savelle \& McCartney 1999; Whitridge 2002). Current zooarchaeological methodologies do not allow for a clear understanding of how often bowhead whales were actively hunted at a given site; the animals' large size demanded only meat, blubber, skin, baleen, and bone useful in architecture or tool manufacture were transported to village sites. It is clear that walrus - the next most substantial animal after bowhead whales hunted by Thule Inuit- - were being exploited at $\mathrm{NeHd}-1$ on a scale not previously seen in any Canadian Arctic cultural context. 
The faunal data from NeHd-1 help to fill a gap in our understanding of the history of walrus exploitation around northern Foxe Basin; when Thule Inuit entered the region, walrus had been intensely exploited by Dorset groups for more than 1000 years. The intensification by Early Dorset on Igloolik coincided with an increase in walrus remains in the fossil record (Dyke et al. 1999: 174). Benthicfeeding walrus require shallow waters $(<100 \mathrm{~m}$.). The rate of isostatic adjustment around Foxe Basin is approximately $70 \mathrm{~cm}$ every 100 years (Dredge 1992). It is likely that Dorset intensification developed as walrus feeding habitat around Foxe Basin increased. Murray (1999) has suggested the resulting large-scale exploitation may have facilitated a rise in human population over time, ultimately shaping social organization among Dorset in the area. Curiously, Late Dorset (c. AD 300 to between 1000 and 1200) reliance on walrus was significantly lower than that of their Early and Middle Dorset ancestors (Murray 1996), despite what must have been an abundance of walrus in Foxe Basin waters, indicating a profusion of resources may not always result in exploitation.

The suggestion that walrus intensification may have affected social institutions is intriguing, considering the presumed social effects of Thule Inuit bowhead whaling. Much of Classic Thule Inuit society is believed to have been organized socially around whaling, a practice eliciting a great deal of regional influence and prestige (Rainey 1947; Spencer 1959; Burch 1981; Whitridge 1999). Like whaling, walrus hunting in western Alaska and the Eastern Arctic was, and remains, a communal activity. Boas (1964 [1888]: 89-93) described the hunting of walrus by nineteenth-century Inuit as being in many ways similar to that of whales, in terms of planning and coordination. Prestige would almost certainly be associated with an abundance of tough walrus hides (for boat covers, boots and lashing) and ivory, used to fashion a variety of items, and found at Thule Inuit sites well outside the range of walrus. Large amounts of ivory may have been traded regularly by the residents of $\mathrm{NeHd}-1$ and other sites in northwest Foxe Basin to Thule Inuit in regions where walrus were either less plentiful, or unavailable.
Though not unexpected considering the singular ecology of Foxe Basin, the high proportion of walrus at $\mathrm{NeHd}-1$ is notable, as it suggests the exploitation of an ecological niche by Thule Inuit residents of the region mirroring that of modern Inuit. The hunting tradition in Igloolik and Hall Beach remains vibrant; the summer walrus hunts out of both communities net an average of 247 animals per year (Priest \& Usher 2004: 270-72).

The possible long-distance trade in ivory among Thule Inuit may be broadly reflective of the contemporary trade in igunaq, aged walrus meat cached in the traditional manner. Igloolik, renowned for "producing some of the tastiest igunaq" in Nunavut (Thompson 2008), makes its annual surplus available through special trade agreements with hunters and trappers associations in communities without access to walrus. This continues to cement the popular association between walrus and the hunters of northern Foxe Basin. Through a fuller understanding of walrus hunting and the use of walrus resources by Thule Inuit, we can begin to address the social and economic importance of a hunting tradition that has sustained Inuit residents of the region for approximately 800 years.

\section{Acknowledgements}

This research would not have been possible without the support of the Inuit Heritage Trust, the Igloolik Research Center and the municipal councils and hunters and trappers associations of Hall Beach and Igloolik. I would especially like to thank the elders and hunters of Igloolik who shared with me their valuable time and knowledge: Solomon Allurut, Luke 'Lukie' Airut, Herve Paniaq, and Itani Paniaq. Julie M. Ross graciously provided the faunal material. James M. Savelle provided a thorough review of a previous version of this paper. I would also like to thank T. Max Friesen for his close supervision and guidance, and this paper's anonymous reviewers for their valuable feedback. The Sanirajak Project was funded primarily through a major grant from the Canadian government's International Polar Year program. Additional funding for my own research included travel grants from the Northern Scientific Training Program, the William E. Taylor Research 
Award from the Canadian Museum of Civilization, and a master's scholarship from the Social Sciences and Humanities Research Council of Canada.

\section{REFERENCES}

Arutiunov S. \& SergeEv, D. 1968. - Two millennia of cultural evolution of Bering Sea hunters. Arctic Anthropology 5(1):72-75.

Beckett J., Chiperzak D., Wheeler B., Hillis T., Ebner D. \& SetTerington M. 2008. - Nunavut wildlife resources and habitat values. Report to the Nunavut Planning Commission, Cambridge Bay. Jacques Whitford, Limited, Yellowknife.

BINFORD L.R. 1978. - Nunamiut ethnoarcheology. Academic Press, New York.

BOAS F. 1964 [1888]. — The Central Eskimo. University of Nebraska Press, Lincoln.

Born E.W., GJERTZ I. \& ReEves R.R. 1995. — Population assessment of the Atlantic walrus (Odobenus rosmarus rosmarus L.). Norsk Polarinstitutt Meddelelser 138.

BurCH JR. E.S. 1981. - The Traditional Eskimo Hunters of Point Hope, Alaska: 1800-1875. North Slope Borough, Barrow, AK.

Collins JR. H.B. 1937. — Archaeology of St. Lawrence Island, Alaska. Smithsonian Institution, Washington, D. C.

Crowe K.J. 1970. - A cultural geography of Northern Foxe Basin, N. W. T. Department of Indian Affairs and Northern Development, Ottawa.

DAMAS D. 1963. - Iglulingmiut kinship and local groupings. National Museum of Canada Bulletin 196. Department of Northern Affairs and Natural Resources, Ottawa.

DAMAS D. 1969. - Environment, history and central Eskimo society, in Damas D. (ed.), Contributions to Anthropology: Ecological Essays. National Museums of Canada Bulletin 230: 40-64.

DARWENT C.M. \& FoIN J. C. 2010. — Zooarchaeological analysis of a Late Dorset and an Early Thule dwelling at Cape Grinnell, northwest Greenland. Geografisk Tidsskrift - Danish Journal of Geography $110(2): 315-336$.

DESJARDINS S.P.A. 2009. - A walrus-based subsistence focus at NeHd-1 (Sanirajak), a Classic Thule Inuit winter site, northwest Foxe Basin, Nunavut. Paper presented at the 42nd Annual Canadian Archaeological Association (CAA) Meeting, Thunder Bay.

Desrosiers P.M., Lofthouse S., Bhiry N., Lemieux A.-M., Monchot H., Gendron D. \& Marguerie D. 2010. - The Qijurittuq site (IbGk-3), eastern Hudson Bay: an IPY interdisciplinary Study. Geografisk Tidsskrift - Danish Journal of Geography $110(2): 227-243$.
DREDGE L. 1992. — The geology of the Igloolik Island area, and sea level changes. Science Institute of the Northwest Territories Report 2. Scientific Services Program, Yellowknife, N. W. T.

Dyke A.S., Hooper J., Harington C.R. \& Savelle J.M. 1999. - The Late Wisconsinan and holocene record of walrus (Odobenus rosmarus) from North America: a review with new data from Arctic and Atlantic Canada. Arctic 52(2):160-181.

FREEMAN M.M.R. 1984. - Arctic ecosystems, in DAMAS D. (ed.), Handbook of North American Indians, Vol. 5. Smithsonian Institution, Washington, D. C.

FRIESEN, T.M. 2004. - Contemporaneity of Dorset and Thule cultures in the North American Arctic: new radiocarbon dates from Victoria Island, Nunavut. Current Anthropology 45(5): 685-691.

Friesen T.M. \& ARNold C.M. 2008. - The timing of the Thule migration: new dates from the Western Canadian Arctic. American Antiquity 73(3): 527-538.

FRIESEN T.M. \& BETTS W. 2004. - Archaeofaunas and architecture: zooarchaeological variability in an Inuit semi-subterranean house, Arctic Canada. Proceedings of the 9th Conference of the International Council of Archaeozoology, Durham: 65-76.

Gotfredsen A.B. 2010. - Faunal remains from the Wollaston Forland - Clavering $\varnothing$ region, northeast Greenland - Thule culture subsistence in a High Arctic polynya and ice-edge habitat. Geografisk Tidsskrift Danish Journal of Geography 110(2): 175-200.

Haulli J. \& Haulli S. 1987. - Interview for the Oral History Project. Inullariit Society oral history archive, Nunavut Research Institute / Igloolik Research Center, Igloolik, NU, (IE015).

HiLl E. 2011. - The historical ecology of walrus exploitation in the North Pacific, in BRAJE T. J. \& RICK T.C. (eds), Human impacts on seals, sea lions and sea otters: integrating archaeology and ecology in the Northeast Pacific. University of California Press, Berkeley.

Howse L. 2008. — Late Dorset caribou hunters: zooarchaeology of the Bell site, Victoria Island. Arctic Anthropology 45(1): 22-40.

IJjANGIAQ T. \& NUTARAKITTUQ E. 1987. — Interview for the Oral History Project. Inullariit Society oral history archive, Nunavut Research Institute / Igloolik Research Center, Igloolik, NU, (IE020).

Ivalu A. 1996. - Interview for the Oral History Project. Inullariit Society oral history archive, Nunavut Research Institute / Igloolik Research Center, Igloolik, NU, (IE355).

KaPPIANAQ G. 1997. — Interview for the Oral History Project. Inullariit Society oral history archive, $\mathrm{Nu}-$ navut Research Institute / Igloolik Research Center, Igloolik, NU, (IE427).

KunuK E. 1998. - Interview for the Oral History Project. Inullariit Society oral history archive, Nunavut Research Institute / Igloolik Research Center, Iglo- 
olik, NU, (IE433).

LEMOINE G.M. \& DARWENT C.M. 1998. — The walrus and the carpenter: Late Dorset ivory working in the High Arctic. Journal of Archaeological Science 25: 73-83.

LOFTHOUSE S.E. 2003. - A taphonomic treatment of Thule zooarchaeological materials from Diana Bay, Nunavik (Arctic Quebec). Unpublished MA thesis, Department of Anthropology, McGill University, Montreal.

LyON G.F. 1825. - Private journal of Captain G. F. Lyon, of H. M. S. Hecla: during the recent voyage of discovery under Captain Parry (new edition). J. Murray, London.

McGHeE R. 1984. - The timing of the Thule migration. Polarforschung 54(1): 1-7.

Mary-Rousselière G. 1976. - The Paleoeskimo in northern Baffinland, in MAXWELL M.S. (ed.), Eastern Arctic prehistory: Paleoeskimo problems, Memoirs of the Society for American Archaeology 31: 40-57.

MARY-ROUSSELIÈRE G. 1954. - The archaeological site of Pingerkalik. Eskimo 6: 11-15.

MATHIASSEN T. 1927. - Archaeology of the Central Eskimos. Report on the Fifth Thule Expedition 1921-1924, 4(1-2). Gyldendalske Boghandel, Nordisk Forlag, Copenhagen.

MATHIASSEN T. 1928. - Material culture of the Iglulik Eskimos. Report on the Fifth Thule Expedition 19211924, 4(1-2). Gyldendalske Boghandel, Nordisk Forlag, Copenhagen.

McCulLOUGH K.M. 1989-1928 - The Ruin Islanders. Ottawa: National Museums of Canada, Mercury Series No. 141.

MELDGAARD J. 1960. — Origin and evolution of Eskimo cultures in the Eastern Arctic. Canadian Geographic Journal 60(2):64-75.

MeldGaARD J. 1962. - On the formative period of the Dorset culture. Arctic Institute of North America Technical Paper 11.

MøHL U. 1979. - Description and analysis of the bone material from Nugarasuk, an Eskimo settlement representative of the Thule Culture in West Greenland, in McCartney A. (ed.), Thule Eskimo culture: an anthropological retrospective. Archaeological Survey of Canada Mercury Series Paper 88: National Museum of Man, Ottawa: 380-394.

MurRaY M.S. 1996. - Economic change in the Paleoeskimo prehistory of the Foxe Basin. N. W. T. Unpublished $\mathrm{PhD}$ dissertation, Department of Anthropology, McMaster University, Hamilton.

MURRAY, M.S. 1999. - Local heroes: the long-term effects of short-term prosperity: an example from the Canadian Arctic. World Archaeology 30(3): 466-483.

Outridge P.M. \& STEWART R.E.A. 1999. - Stock discrimination of Atlantic walrus (Odobenus rosmarus rosmarus) in the Eastern Canadian Arctic using lead isotope and element signatures in teeth. Canadian Journal of Fisheries and Aquatic Sciences 56(1): 105-112.

PARK R.W. 1989. - Porden Point: an intrasite approach to settlement system analysis. Unpublished $\mathrm{PhD}$ dissertation, Department of Anthropology, University of Alberta, Edmonton.

PARRY, W.E. 1824. - Journal of a second voyage for the discovery of a North-West Passage from the Atlantic to the Pacific: performed in the years 1821-22-23 ... under the orders of Captain William Edward Parry. J. Murray, London.

PATTON A.K.B. 1996. - The ideological dimensions of whale bone use in Thule winter houses. Unpublished MA thesis, Department of Anthropology, McGill University, Montreal.

PrIest H. \& Usher P.J. 2004. - The Nunavut wildlife harvest study. Nunavut Wildlife Management Board, Iqaluit.

QAMANIQ N. 1999. - Interview for the Oral History Project. Inullariit Society oral history archive, Nunavut Research Institute / Igloolik Research Center, Igloolik, NU, (IE420).

RAINEY F.G. 1947. - The whale hunters of Tigara. Anthropological Papers of the American Museum of Natural History 41(2): 231-283.

RicK A.M. 1980. - Non-cetacean vertebrate remains from two Thule winter houses on Somerset Island, N.W.T. Canadian Journal of Archaeology 4: 99-117.

SABO G. 1981. - Thule culture adaptations on the south coast of Baffin Island. Unpublished $\mathrm{PhD}$ dissertation, Department of Anthropology, Michigan State University, East Lansing.

SAVELLE J.M. 1997. - The role of architectural utility in the formation of zooarchaeological whale bone assemblages. Journal of Archaeological Science. 24: 869-885.

SAVElle J.M., Friesen T.M. \& LyMAN, R.L. 1996. Derivation and application of an otariid meat utility index. Journal of Archaeological Science 23:705-712.

Savelle J. \& MCCartney A.P. 1999. — Thule Eskimo Bowhead Whale Interception Strategies. World Archaeology 30:437-451.

SPENCER R.F. 1959. - The North Alaskan Eskimo: a study in ecology and society. Bureau of American Ethnology Bulletin 171.

STAAB M.L. 1979. - Analysis of faunal material recovered from a Thule Eskimo site on the island of Silumiut, N.W.T., Canada, in McCartney A.P. (ed.), Thule Eskimo culture: an anthropological retrospective, Archaeological Survey of Canada Mercury Series Paper 88: National Museum of Man, Ottawa: 349-379.

STIRLING I. 1997. - The importance of polynyas, ice edges, and leads to marine mammals and birds. Journal of Marine Systems 10: 9-21.

STENTON D.R.1987. — Recent archaeological investigations in Frobisher Bay, Baffin Island, N.W.T. Canadian Journal of Archaeology 11: 13-48.

SWINARTON L. 2008. - Animals and the precontact Inuit of Labrador: an examination using faunal remains, space and myth. Unpublished MA thesis, Department of 
Anthropology, Memorial University of Newfoundland, St. John's.

TAYLOR JR. W.E. \& MCGHEE R. 1979. — Archaeological material from Cresweall Bay, N. W. T., Canada. Archaeological Survey of Canada Mercury Series, Paper 85. National Museum of Man: Ottawa.

ThOMPSON J. 2008. - Will Igloolik choose iron mine jobs over igunaq? Nunatsiaq News, April 11.

THOMSON J.C. 1991. - Report on Archeological Testing of the Watamaniuk site (NeHd-1), July 1990, Ms. 3310, Project No. 7017. Jacques Whitford and Associates, Yellowknife.

VAN NORMAN R.D. 1955. - Report on ancient Eskimo dwellings at Site Thirty. Report to the Department of Northern Affairs and Natural Resources, Ms. 710. Archaeological Survey of Canada, Ottawa.

WeNZEL G.W. 1978. - The harp-seal controversy and the Inuit economy. Arctic 31(1): 2-6.

WHITRIDGE P. 1999. - The construction of social difference in a prehistoric Inuit whaling community. Unpublished $\mathrm{PhD}$ dissertation, Department of Anthropology, Arizona State University, Phoenix.

WhitRIDGe P. 2001. — Zen fish: a consideration of the discordance between artifactual and zooarchaeological indicators of Thule Inuit fish use. Journal of Anthropological Archaeology 20: 3-72.

WhitRIDGE P. 2002. - Social and ritual determinants of whale bone transport at a Classic Thule winter site in the Canadian Arctic. International Journal of Osteoarchaeology 12: 65-75.

Pers. COMm.: Allurut S. 2011. — Resident, Igloolik, NU, interview with Desjardins S.P.A.

Pers. COMm.: PaniaQ H. 2011. - Elder and hunter, Igloolik, NU, interview with Desjardins S.P.A.

Submitted on 27th December 2011; accepted on 12th February 2013. 